\title{
Moral Education
}

\author{
Dr. Jamal Fawaz Mansour Alomari \\ Dept of Basic Science, Princes Rahma University College \\ Al-Balqa' Applied University, Jordan \\ Tel: 962-5251-0563Ｅ-mail: Drjamal@bau.edu.jo
}

Dr. Mohammad Ibraheem Saleem Abu Jerban

Dept of Basic Science, Princes Rahma University College

Al-Balqa' Applied University, Jordan

Tel: 962-5325-0071 E-mail: Mohammad Abu jreban @ yahoo.com

\author{
Dr. Abdullah Ahmed Abd Alaziz Al Awamleh \\ Dept of Basic Science, Princes Rahma University College \\ Al-Balqa' Applied University, Jordan \\ Tel: 962-5351-0563Ｅ-mail: Awamlelha@.yahoo.com
}

Received: December 08, 2010 Accepted: January 9, $2011 \quad$ Published: December 27, 2011

doi:10.5296/ije.v3i2.1257 URL: http://dx.doi.org/10.5296/ije.v3i2.1257

\begin{abstract}
This research focuses on the most important issue that contributes in the educational process producing it with values and attitudes that help all teachers face difficulties.

Morals are the basic element that all generations should learn and apply for that it's the core of all religions, so Scientists declare its roots, aims, and effects on individuals and groups. As it's mentioned in this research, in order to link this idea with reality, this research explains the practical application for some educational values as justice, shyness, loving others and honesty.
\end{abstract}

Keywords: Moral Education, Values, Stages of moral education, Origins of morals and its features 


\section{Introduction}

Thank God for giving us his gifts in creating humans in full picture and distinguishing him above other creatures. So God ordered the angels to show respect to humans. This was shown through worship spreading love and forgiveness among people: as said in the verse" $O$ mankind! Lo! We have created you from male and female, and have made you nations and tribes that ye may know one another. Lo! TAhe noblest of you, in the sight of Allah, is the best in conduct. Lo! Allah is Knower, Aware. Alhugerat verse "13". (Holy Quran)

Every enduring community has a moral Code and it is the responsibility and the concern of it's adults to instill this code in the hearts and minds of its young. When the first common schools were founded in the New World, Moral education has the prime concern New England puritans believed moral code resided in the Bible, therefore, it was imperative that children be taught to read, has having access its grounding wisdom.

In the nineteenth century. As the young republic took shape, schooling was promoted for both secular and moral reasons. In 1832 a time when some of the founding fathers were still alive, Abraham Lincoln wrote in his first political announcement (March, 9, 1839) "(I desire to see a time when education, and by its means, morality, sobriety, enterprise, and industry, shall become much more general than at present”.

In the nineteenth century, teachers were hired and trained with the clear expectation that they would advance the moral mission of the school and attend to character formation.

Literature, biography, and history were taught with the explicit intention of infusing children with high moral standards and good examples to guide their lives.

In the twentieth centaury, there was also a growing reaction against organized religion and the belief in a spiritual dimension of human existence. Intellectual leaders and writers were deeply influenced by the ideas of the English naturalist Charles Darwin, the German political philosopher Karl Marx. Therefore, moral education had a religious tinge, which made many uneasy. (http//education.stateuniversity.com/pages2246/moral- education.htm)

According to Wilson et.al(1967, p.129): “a child needs to accept a certain code of behavior, parental commands, traditional rules etc." of course, all children have their own interpretations of moral concepts, and obeying these different rules in different situations was the first clue that they were flexible and depend on different factors. So, morals and morality pervade every aspect of our lives. Therefore, it needs to be searched. (http//education.stateuniversity.com/pages2246/moral- education.htm)

So humans rising up within this social media situation and dealing with each other within some basic morals. In order to win the group approval and achieving security and peace and all of these are the basic of moral system for that, educators focus on morals since they are the one of the most important philosophical topics concerning human's life. Also all religions focus on that topic. Holy Quran was a whole Constitution, for morals and literature in all fields, and it includes interpretations. (Al Bukaree, 2008) 


\section{The importance of topic and its thesis}

Without doubt, this topic is considered to be the most important topic concerning education since it puts it into its role that needs understanding of ideas, concepts Attitudes, which are related to morals, values and religions.

\section{Previous studies}

There are some books that researches related to this topic just like:

1) Children Education in Islam, for Abdullah Naseh Elwan, he concentrates on: - Moral Education in Islam.

2) Islamic Moral Education for Mugdad Yalgen.

3) Moral Education / Research for Muhammad Jehad Al Jamal.

4) Moral Education / Rsearch for Adnan harth.

In a study entitled with an analyses of the effect sacred and secular moral education on moral behavior in American public school. ( ladona, 2010.p620)

It found that the church played the great role in moral behavior among adults since they do come to pray and it found Christian faith provides young people with a consistent moral guide for applying right morals. In another study entitled with Moral education and sport. (sunjoo, 2010)

It found that sport can play a great role in moral education since it activates people in intellectual ability that provide them with right behaviors.

\section{Research plan}

This study includes introduction, four topics and conclusion as follows:

1) Introduction: It contains the topic importance and thesis, the previous literature and the study plan.

2) The first topic was about the meaning of the Moral System concept in Islam and Its importance and legality.

3) The second topic was about the origins of morals and its characteristics. Therefore, this topic came in two dimensions.

4) The third topic was about the aim of moral education and its consequences on individuals and groups.

5) The fourth topic includes practical applications for moral Education. Therefore, this topic came in two dimensions.

6) Conclusions include the most important recommendations that the research finds. 


\section{The first topic: The Meaning of Moral System in Islam, Importance, legality}

\subsection{First in language}

Morals are religion, habits, innocent, it reveals the inner humans self, so this meaning shows values, nature and abstract objects as AlEmam Al Qurtbi said" Moral in language means whatever the human gets from good behavior(Ibn mendur,1997)

\subsection{Second: Morals as terms}

AlEmam Al Gazali defines Moral as a Stat of self that produces actions easily without a need for thought or insight both actions, bad or good relates to morals (Al Gazali.1987) so he defines morals as constant, and aren't forced, wich means that morals are behavioral rules that constrain People to act. AlEmam Al Razi: defines moral as basics that help people act well.(AL Razi,1987) and this is a requirement from the modern Education which shows that moral action is an action that we mean to act, this means that moral consists of the process of self adopt to action (karl,1999) and this meaning shows that morals are divided into two parts: first: good and bad; on one hand good morals leads human to do good things, on the other hand bad morals lead to hate, insult others. Mortality defined a sense of behavioral conduct that differentiates intentions decisions between those that are good and bad amoral code is a system of Mortality ffor example according particular philosophy religion culture as in encyclopedia.

\subsection{Second aspect Moral importance and its legality}

No researcher doubts the fact that morals are the core of all religions and it's as a heart in Islam, so morals interact with life systems and principles, especially in Islamic system, which build on the right morality basics. Also, Islam calls for good morals, especially in Holly Quran and it considered it one of the most important values of faith as God says: "It is not righteous that ye turn your faces to the East and the West; but righteous is he who believeth in Allah and the Last Day and the angels and the Scripture and the prophets" Albaqara verse (77).(Hloy qran)

Ghutadah said, a man came to profit Mohammad asked about righteous so God said that faith leads to paradise (B) God says: "And lo! thou art of a tremendous nature "Al Qalam verse 4. and Almam Ibn kather interprets this as Islam or great moral (kareem,2001) so religion scientist said that religion is moral, so if anyone gets more morality than others he get higher degree in religion (Ibn Alqeem.2003), as profit Mohammad said; (Al Bukaree, 2008)

A: the perfect people are those who have got morals. (Al-Hadeeth, 2005)

B: I came to complished good morals (Al-Hadeeth, 2005) (Al Bukaree, 2008)

C: the heaviest in the balance in the last day is faith and good morals. (Al-Hadeeth, 2005)

D: A man asked profit Mohammad to advise me: he said, "have faith in God said, more, he said, treat people with good morals (Al-Hadeeth, 2005) so profit Mohammad grows good morals and values among Muslims and he practised with them methods of education through giving them modals and advice as said by Alashaj: profit Mohammad (peace upon him) that 
this man has two characteristics that are dream and patience, he asked new or old, he said, old. The man said thanks God for this (Al-Hadeeth, 2005) Because of this, Islam focuses on moral education for bringing up good generations; the importance of moral education in Islam came from the idea that morals are a group of morality principles, behaviors and emotions, which Muslims must have from his early childhood. (Al Bukaree, 2008) Also morals are grounded in Christianity, which is focused on instructions that Jesus Christ grounded in people such as honesty, loyalty, and good behaviors.

Jesus was the model for all people in good morals and behaviors and spreaded his instructions to all people to follow. It started from the church, then books in order to ask people to fillful their needs through knowing God and Applying good, right morals as mentioned (Naser.2004).

In the moral theory according to john Dewy the considered morals as a method or away for solving moral problems and it is used scientific way in natural sciences .Also in Kant is moral theory, he critised the practical mind and said that moral same the grounds which makes mind free.

5.4 Stages of moral education and researchers believe that moral education with the following phases: The beginning of ethics

What is the stage that begins where ethics and moral education? The answer is that it begins in the early months when the child begins to find some kind of link with his parents smile that smile on his face. Some might think that talking about such thing as morality in such a phase seems strange, while studies have shown facts contradict this perception.

There is a moral assets of the child should be taught from that period, so that we are duty-bound to seek to teach some of the habits commensurate with that age. Child psychologists finds that the characteristics of the child and printing shape since the days of breast feeding and childhood, and on this basis must be the start of moral education since that time early. Because the delay would lead to serious difficulties in future. Reflected in the child concepts of righteousness, and knowledge of duties, and respect for others at about the third year of his age, at this stage to take shape and the basic moral conscience, no ability to diagnose it the ugly beautiful. In Missourna educated noble concepts such as compassion, and high vigor and endurance, to form the solid base to strengthen his character primary bases: it is necessary to mention here that education should be in any stage of the complement of the previous session and setting for the subsequent session. That lack of time, and the short-lived does not allow us to teach the child things we have in the post to be erased from his mind, especially after the deep-rooted and that threads in his mind and instil moral habits of self be uprooted from the very difficult things.

It also has to be drawn to the foundations of morality in the primary is of extreme importance. rights grow in 4 to 7 years and highlights the nature of the individual and the child becomes then need more perseverance and attention. This remains a need to prove that ethical behavior in personal and teaches educators and parents that the first five years of age the most important years of life, and make up by educators as the basis of years of living because the 
qualities and assets built in. You have to have learned good manners since childhood, and respect for others, and strive to acquire the courage and generosity and compassion, and to lend his things for special to others ... Etc. Second: is part of childhood in the scope of the second seven years of age, at this stage to take education seriously and official character, and where the child is responsible for the actions of him, will be inmoral and assets. the child at the primary level is not an angel pure and ascetic in the world to expect his affairs at your will; but he lives in the atmosphere of school charged noise and clamor and dominated the atmosphere is concerned about competition intense, then it is in this case you require to impoe some control over some of them. Thoudy the issue of role models at this stage something of importance; because the ethics of the child getting dragged behind Maysma and see, or as it is said that his views in this regard issued by the realistic picture. And, they must of course be in order for this command a logical indicative based on religious grounds. When you hold the controls we must observe the factors age and understanding, perception, and sexual maturity. Appear on the child within the year (9-12) Specifications ethical imperatives remain inherent normally until adulthood, and becomes friends a role in his life during this stage, and the affect it also directed the parents, and encouragement and inhibition it receives from adults, and the teacher should try to configure the control Interior of the child in order to be prepared ground between the ages of 6 and 10 years.

\section{The second topic: Origins of morals and its features}

\subsection{First need, origins of moral in Islamic constitution}

First origins: Includes wills that help people be great among others in all fields as purity; as mentioned by AlEmam Al Dahooli (Al Dahooli,2001) which means getting all good morals and this happens just because of worship and this was shown as said by $\mathrm{Al}$ jaleel Aseed on Hudear " as I was reading Albagara verse at right, the horse moved then I stopped reading, then stopped reading, then I raised my head up to sky and isaw alarg cloud with something, so in the morning asked profit Mohammad whose that he said those are angels who were listening to you. (Al-Hadeeth, 2005), also, Albara Bn Azeb defines that by, that man was reading $\mathrm{Al}$ kahf verse and he had a horse tide by two ropes then a cloud began to get closer to him and in the morning he asked profit Mohammad (peace upon him) what happened with him so profit Mohammad told him it's the mercy get down just for the holly quern's. (Al-Hadeeth, 2005).

Morals are reinforced in education which contributes to good things as followed by Profit Mohammad. (Al-Hadeeth, 2005). AlEmam Al Nawawee said, that faithfulness in worship is beneficial. (Al Nawawee, 1999)

\section{The second origin}

Includes giving right for others, be away from execution, as in verse 10 Alhugrat " The believers are naught else than brothers. Therefore make peace between your brethren and observe your duty to Allah that haply ye may obtain mercy", and verse 29 Alfateh "Muhammad is the messenger of Allah. And those with him are hard against the disbelievers and merciful among themselves" as said by others that a group of people came to profit 
Mohammad and said that a woman fasts all days but she is bad so he said, she is bad. (Al-Hadeeth, 2005)

\section{The third origin}

Justice it is a stat of self that controls people. So it is a kind of good behaviors that is grounded in humans but if it deals with man daily conditions its called moral and if it deal with financial its called competence but if it deal with managing house its called freedom. The basic in getting justice as mentioned by Alamam Al Dahooli is represented in mercy and love and looking for the consequences of things. (Al Dahooli, 2001).

As our god warned us of envy shown in al Nes'a, verse (54) "Or are they jealous of mankind because of that which Allah of His bounty hath bestowed upon them? For we bestowed upon the house of Abraham (of old) the Scripture and wisdom, and we bestowed on them a mighty kingdom".

Profit Mohammad warned people of envy. As he said " don't envy because it eats good acts as the fair eats wood.(Al-Hadeeth,2005) so we can said that envy isn't good moral and we should get away from it and that is clear in the holey Quran( alhaj.Verse_11). "And among mankind is he who worshipped Allah upon a narrow marge so that if good befalleth him he is content therewith, but if a trial befalleth him, he falleth away utterly. He loseth both the world and the Hereafter. That is the sheer loss"

\section{The second need: Features of moral system in Islam}

First: Faith , being straight and being correct are the translations for faith and this cant be achieved without consciousness(Shaded,2001) so all religions and profits asked for morals so all researchers in the English conference, in achieving Education, in the year 1907 agreed on that morals relate to religion (Nasser,2004) and without education there is no results(Alwan,2001) and because of the importance of this slagon (no morals without religion, there were a lot of philosophers as the German philosopher Pheakta, (Alwan,2001) and there was Dorkayem who asked for separating religion from morals but by the end of his work, he believed that there is a relation between morals and religion and its not easy to separate one form another. (Baherth, 2010)

\subsection{Second:-Consistency, comprehensively and reality}

What distinguishes moral education in Islam is that it is taken from Holly Quran so there should be loyalty and honesty Islam considers consistency, honesty, patience, loyalty and shyness to be the most important features of Islamic morals (Baherth,2010) and because of money and individuality people were away from faith and morals .(Almawerdi,1998)

Profits Mohammad said, worshipper for worshipper as one unit (36). So Islam focuses on loyalty and keeping on truce, as the story of Summer and which was, the people there, complained about the military leader Gutebeh when he asked them to leave their country and Alkelefh Omer Ibn Abd Alazeez asked his judge to judge that and he judged them to leave their countries .(Al-Hadeeth,2005). 
Loyalty is considered to be the most effective morals in the state behaviors during the Islamic history as when Maweiya Ibn Abe Sufain moved his army to his enemy and when he gets closer to them, Amro Bn Anbeh said to him with the Greatest God honest but dishonest . (Al-Hadeeth, 2005)

Morals in Islam are fixed and holistic and realistic for that our God had never ordered us to do something only if we have the ability to do it as in verse Alba Kara " Allah tasketh not a soul beyond its scope "286. The realistic of morals in Islam get a clear picture when the balance manufacture between soul and body as in verse Alba Kara " $O$ ye who believe! Eat of the good things wherewith we have provided you, and render thanks to Allah if it is (indeed) He whom ye worship "172. and as profit Mohammed said," God likes to see his wealth on people. (Al-Hadeeth, 2005).

9.2 The third topic: The Objectives of Moral Education: It's Effect on Individual first and Groups. Need: Objective

It is engrounding and supporting morals in people in all fields 42 in modern education researchers as John Dewey said Moral development is the outcome of school 43, so developing good morals are one, which support personality. The origins are:

1. from Holy Quran: As verse" 122" Altawbah," And the believers should not all go out to fight. Of every troop of them, a party only should go forth, that they (who are left behind) may gain sound knowledge in religion" this means that worshippers are spreading, ones leave, the other stay and followed rules, and laws ( Ibn arabe,1998) and God said, " Our Lord! And raise up in their midst a messenger from among them who shall recite unto them Thy revelations, and shall instruct them in the Scripture and in wisdom and shall make them grow. Lo! Thou, only Thou, art the Mighty, Wise. As verses Alba Kara 129. In addition, as in verses 19 Mohammed "So know (O Muhammad) that there is no God save Allah, and ask forgiveness for thy sin and for believing men and believing women. Allah knoweth (both) your place of turmoil and your place of rest". In addition, the maturity of morals in people is shown into two points.

1) To know real right.

2) To know good things to do (AlRazi,2001)

3) from Islamic constitution

Profit Mohamed said, the nearest one in the last day to me is the best in morals 46 .

This means that the best in morals complete his faith and religion then he becomes Muslim (Aljien, 1983) also he said, the best Muslim is the best in morals. (Al-Hadeeth, 2005) also profit Mohammad guides a man to keep God so God keeps him also help you. (Al-Hadeeth, 2005) also he said," say I have faith in God and then be straight” these all lead you to faith and morals.

\section{The second need: The effect of Moral Education on individual and group}

Islam encourages good morals since they have effect such as: 
1) Its true translation for Islamic lessons and guidelines, which are considered to be the standards for worship. (Alkelani, 1992).

2) Its recovering from illness for individuals as tension mental diseases. Alrazi said in his interpretation of Gods saying verse/ 82/ Al Israa "And We reveal of the Qur'an that which is a healing and a mercy for believers though it increase the evil-doers in naught save ruin." That al Quran recovers people from spiritual diseases.(Alrazi,2001)

3) It's a base for helping individuals be with God as a whole plan including good morals.

4) Feeling happiness and this is show a through working in life for the last day as Prophet Mohammed said," am a leader in heaven for those whom had a good moral.

5) Its considered be the first support for keeping nations and communities

As Dewy said, the neglecting of morals, education leads to late society (Al Bukaree, 2008) so moral Education advances civilization in two points:

First: keeping it from collapsing

Second: moving it forward (Yaljien, 1983).

Also moral education in Islam develops positive spirit that reflects on social system as in verse al emran "And there may spring from you a nation who invite to goodness, and enjoin right conduct and forbid indecency. Such are they who are successful " (104) so moral education is the main reason to build a good and bower society otherwise in the absence of moral education there will be a breakdown in society as in verse Al hage" How many a township have We destroyed while it was sinful, so that it loath (to this day) in ruins"(45).

\section{The fourth topic: Realistic application for moral education first need justice and shyness}

\subsection{First: justice}

Its a good feature that Islam asks for which means straightness as Mohammad Abu Zahra said justice is the straight balance that defines relations among people in peace and war Abu Zahra, 1996).God said God asks you to give honesty and judge justices Al Nesa verse 58" Lo! Allah commanded you that ye restore deposits to their owners, and, if ye judge between mankind, that ye judge justly. Lo! comely is this, which Allah admonisheth you. Lo! Allah is ever Hearer, Seer". In addition, Alrazi said the judge should judge with fair (62) and is a way of Education activity towards nations.

\subsection{Second: Shyness}

Its one of the most important morals that Islam asks for as profit Mohamed said, each religion has a moral and Islam moral is shyness. (Al hadeeth, 2005)

The second need:-Honesty and loving others: 


\subsection{First honesty}

Is a good moral that Islam asks for since it is the people settlement and it is a kind of help for people. God says describing his profit Mention in the holy book, Ibrahim that he was a profit with honesty as in Meryam verse " And make mention (O Muhammad) in the Scripture of Abraham. Lo! He was a saint, a prophet "(41).

Therefore, Islam focuses on developing honesty approach in bringing up children and warn people from lies in front of them as profit Mohammad said "hill to whom talk to other in order to make them laugh and hill to him.(Al hadeeth,2005) (Al Trmethi,2008)

Abdullah Ebn Amer said that my mother asked me on day while profit Mohammad sitting in our home and said come to give you something; so profit Mohammad asks her what you are going to give him, she said, I want to give him Phoenix dactylifera, so profit Mohammad said as if you didn't give him anything you will be a liar, (Al hadeeth, 2005) upon to Ayshah om $\mathrm{Al}$ mu'mneen she said ' there is no bad moral to profit Mohammad as laiying. (Al hadeeth, 2005). (Abo Daood, 1973)

\subsection{Second: loving others}

Its one of the most lovely morals that Islam asked for especially giving gifts to others (Tbarh, 1997) Al Qurtbi said, loving others is giving things to others and should be patient. (Alqurtbi, 2001).

God complemented this feature in his book Holy Quran as in verse 9 Al hasher" Those who entered the city and the faith before them love those who flee unto them for refuge, and find in their breasts no need for that which hath been given them, but prefer (the fugitives) above themselves though poverty become their lot. And whoso is saved from his own avarice - such are they who are successful".

\section{Conclusion}

The most important ideas that this research finds are:

1) The important of Moral Education and its importance for people.

2) Cooperation should be started in this century for developing generations through engrounding moral.

3) Building up moral isn't an easy issue but its necessity needs patience for Educators.

4) Traing, Following up, good guidance help us building up morals.

5) Our Islamic constitution and heritage should be considered in creating morals.

6) Holly Quran is the basic document for morals

7) Faith and morals are always Cooperative; they shouldn't be separated. 
8) Hence, the educators should be aware that Ieoh and in particular due to the fact that moral education is responsible for: Providing the individual rules of behavior, values, norms, customs and what to do or leave it.

9) Turn the gain of the rules of behavior acts in a socially acceptable.

10) Planting and give learners good conduct to the fact that ethical behavior when earned passing phases and levels.

11) Learn the means by which the individual from moral behavior while dealing with situations that do not appear negatively consistent with the principles and rules of ethics, customs and traditions.

12) Emanates from the Education and which are the sources ribavirin Educational moral security, love and peace, as if no value for the upbringing and education free of rules and the foundations of the involvement community cohesion to become the one hand and one heart beat with love and life for all is not a value for the upbringing and education also without give the community ethic grows out of which benign behavior of printed Btabaa affection for the community to become one nation in one body so that education and security are inseparable inseparably united each other. It is clear that a good example of the father and mother and big brothers, teachers, educators, neighbors and relatives is an important factor in giving ethical behavior and sound ethical principles. Education is the ethical means raising the individual to become a human being integrated from a moral to be after a key to good Mglaca of evil, and therefore the ethical behavior is the real field and the actual application and practical education Educational ethical, Are we going to do that in our role and our schools and our roads and Tjmatna and conversations and to sell us and our purchases and our dealings.

\section{References}

[Online] Available: http//education.stateuniversity.com/pages2246/moral- education.htm.

Abo Daood, Sulemam Ibn Al Asha'th. (1973). Dar Al hadeeth. Cario, Egypt.

Abu Zahra , Mastfa. (1996). Social morals. Amman.joradn.

Al Bukaree, Mohmad Ibn Esma'eel. (2008). Al Jame'e Al Saheeh. (Saheeh Al Bukaree). Dar al jeel, Beruet, Lebanon.

Al Dahooli, Wahbeh. (2001). Internatal Relaftions In Islam .print 1. Amman, Jordan.

Al Nawee, Abu Zakarie. (1999). What lases the world. Dar alglami,Lebonon

Al Razi, Alfaker. (1987). Al Tafseer Al Kabeer. Dar Eyhei'a AL Turath, print1, Beruet. Lebanon.

Al Razi, Alfaker. (2001). Al Tafseer Al Kabeer. Dar Eyhei'a AL Turath,print 3 Beruet. Lebanon. 
Al Trmethi, Mohmmad Ibn Essa. (2008). Al Jame'e Al Saheeh. (Sunan AL trmethi) Dar Al hadeeth, Cario, Egypt.

Alkelani, Majed Arsan. (1992). New trends in Moral Education. Amman.jordan.

Almarodi. (1985). Abu althassan alibn mohmad and moral education. Dar alktbi, Lebanon.

AlQazahli. (1987). Hjt alslam abe Hamed. Dar al aln, berait language.

Alshatbe, Abramem bn musa. (1994). Agreements, in origins of constition. Dar al marfa, beriut. Lebanon

Alwan, Abdulleh nasesh. (2001). Bringing up Children. Amman,jordan.

Batharth, Adnan. (2010) .Moral Education. [Online] Available: www.Bahareth.org

Carl ,Fluje john. (2001). Humman , marals, and society. Dar alfker.amman,Jordan.

Devine,Susan. (2010). What is moral education. [Online] Available: www.lib.org.

Ibn Algeem. (2003) Shams al Deer Abumearfha. Abdullah dar alktabi, alarbi, Lebanon

Ibn Fares, ahmed. (1996). Dictionary. Dar Alfker, Jordan.

Ibn Haunble, ahmed. (1987). Dar Sader. Beruet, Lebanon.

Ibn Mandoor, Abu al Fadi jamal aldeem. (1998). Arab Tongue. Dar sadr, beriuit .

Kareem, Rajeh Mohmmad. (1986). Muktasar Tafseer Ibn Katheer, 2ed. Dar Al Ma'irfha, Beruet, Lebanon

Ladona,clayton. (2010). An analysis of Effect of sacred and seacular moral education on moral behavior in American public education. DAI, Oral Roberts Universitypages620;AAT3429031

Naser Ibraheem. (2004). Moral Education, print, 1. dar wail. Amman-jordan

Sheded, Muhamad .(2001). Holy Quran in education. Beriut. Lebanon

Sungjoo, Park. (2010). Moral Education and sport. DAI, The Ohio University,149pages,AAT 3424568.

Tabarh, Afreef. (1997) Spirit of Islam. Amman, Jordan.

Yl jen, Mgdad. (1999). Education in islam. Alkanje in Egypt.

\section{Copyright Disclaimer}

Copyright reserved by the author(s).

This article is an open-access article distributed under the terms and conditions of the Creative Commons Attribution license (http://creativecommons.org/licenses/by/3.0/). 